\title{
Dinamika Sosio-Ekonomi Pedagang Santri dalam Mengembangkan Industri Kretek di Kudus, 1912-1930
}

\author{
Muhamad Yusrul Hana \\ Mahasiswa Program Magister Sejarah dan Kebudayaan Islam UIN Sunan \\ Kalijaga Yogyakarta \\ yusrulhana33@gmail.com
}

\begin{abstract}
This paper explain about study on local history on the economic action of santri trader in kretek industry in Kudus 1912-1930. The early trading system of kretek cigarettes was dominated by santri trader until Chinese began producing kretek cigarettes as well, which causes significant profit decline for santri trader. It raised socio-economic tension between the two ethnic due to economic rivalry relations. In the middle of 1912, Chinese merchants started taking over kretek cigarettes market in Kudus. The rivalry matters turns out to be a competition and reach its peak on October 1918 when santri Kudus commence attacking and destroying homes and shops owned by chinese. The falling economic of Chinese, has made Nitisemito and H.M Muslich (Santri trader figure) motivated to maximize their ability in developing kretek cigarette trading system in Kudus. There are several main points that will be explained furthermore in this study. First, the depict of construction between santri traders and chinese merchants in Kudus, second, the effort of Nitisemito and H.M. Muslich in founding kretek cigarettes factory, third, understanding of sosioeconomic patterns and economic action of santri trader in Kudus. The methode that be used in this study is historical research contains heuristic, criticism, interpretation, and historiography.
\end{abstract}

Keywords: economic action, santri trader, kretek industry

\begin{abstract}
Abstrak
Tulisan ini menjelaskan mengenai studi sejarah lokal tentang tindakan ekonomi pedagang santri dalam industri kretek di Kudus 1912-1930. Awalnya sistem perdagangan rokok kretek didominasi oleh pedagang santri sampai orang China mulai memproduksi rokok kretek juga, yang menyebabkan penurunan keuntungan yang signifikan bagi pedagang santri. Ini menimbulkan ketegangan sosio-ekonomi antara dua etnis karena hubungan persaingan ekonomi. Pada pertengahan tahun 1912, pedagang Cina mulai mengambil alih pasar rokok kretek di Kudus. Masalah persaingan ternyata menjadi sebuah kompetisi dan mencapai puncaknya pada bulan Oktober 1918 ketika santri Kudus mulai menyerang dan menghancurkan rumah dan toko yang dimiliki oleh orang cina. Jatuhnya ekonomi orang Cina, membuat Nitisemito dan H.M Muslich (tokoh pedagang Santri) termotivasi untuk memaksimalkan kemampuan mereka dalam mengembangkan sistem perdagangan rokok kretek di Kudus. Pembahasan yang akan dikaji dalam penelitian ini meliputi beberapa hal penting. Pertama, menggambarkan konstruksi dan interaksi sosio-ekonomi antara pedagang santri dan Cina di Kudus, kedua, menggambarkan Nitisemito dan H.M. Muslich dalam mendirikan pabrik rokok kretek, ketiga, mengenali pola-pola sosio-ekonomi dan tindakan ekonomi pedagang santri di Kudus. Metode yang digunakan dalam penelitian ini adalah metode penelitian sejarah meliputi heuristik, kritik, interpretasi, dan historiografi.
\end{abstract}

Kata kunci: tindakan ekonomi, pedagang santri, industri kretek 


\section{PENDAHULUAN}

Merebaknya perdagangan di berbagai wilayah tidak bisa dilepaskan dari peran santri dalam aktivitas ekonomi. Pada awal abad ke-20 kegiatan perdagangan di daerah pesisir pantai utara Jawa banyak mengalami perkembangan. Terjadi beberapa pertumbuhan industri yang cukup besar untuk menjamin kelangsungan hidup masyarakat daerah tersebut. Pertumbuhan ini merangsang industri-industri lain untuk membangun kejayaannya dalam bidang ekonomi. Para pedagang ini yang menjadikan dirinya sebagai seorang santri yang tergolong dalam kelas sosial baru atau santri borjuis.

Para pedagang santri banyak mengembangkan ekonomi industri di Kudus. Salah satu industri yang cukup besar di tahun 1930-an, yaitu pembuatan rokok kretek. Menurut Parada Harahap yang berkeliling Jawa dan mengunjungi beberapa pabrik rokok besar di Kudus pada 1939-1940 M, menuliskan bahwa setiap pagi hari banyak karyawan yang pergi bekerja ke pabrik-pabrik rokok kretek. ${ }^{1}$ Industri ini juga banyak menyerap ribuan tenaga kerja dengan tugasnya masing-masing.

Aktivitas ekonomi santri yang di padukan dengan aktivitas agama, secara sosio-budaya dipandang sebagai ajaran yang dibawa oleh Sunan Kudus (Ja'far Shodiq). Khususnya santri yang berada di Kudus Barat, masih sangat memegang erat tradisi-tradisi Islam murni ini. Pedagang santri Kudus mempunyai karakter dasar dalam berdagang, terutama santri yang berada di Kudus Barat. Mereka berperilaku dengan berdasar pada perilaku Bagus, Ngaji, dan Berdagang (gusjigang). ${ }^{2}$ Perilaku ini dikonseptualisasikan dari perilaku Sunan Kudus. Secara mendasar karakteristik kehidupan ini yang menjadikan pembeda dengan pedagang santri di daerah lainnya.

Perilaku kehidupan gusjigang mentransformasi masyarakat santri Kudus menjadi seorang yang mempunyai tingkat spiritual tinggi dalam kehidupan perdagangan. Apabila ditelisik lebih jauh, santri-santri ini terbentuk dari beberapa unsur seperti soiologis, antropologis, dan psikologis yang bersinergi membentuk keberagaman yang integratif. Keberagamaan ini membawa pedagang santri pada ketakwaan yang bercirikan keseimbangan antara wirausaha, bersyukur, bersedekah, beristighfar, bertaubat, dan bertransendensi. ${ }^{3}$ Dasar ini yang menjadikan pedagang santri Kudus menjadi pribadi yang mempunyai etos kerja tinggi dan berdasar agama yang kuat.

Ketahanan kehidupan pedagang santri mulai di uji setelah mendapatkan pesaing dari pedagang-pedagang Cina. Pedagang santri awalnya menguasai sistem perdagangan rokok kretek di Kudus. Namun keadaan ini

\footnotetext{
1 Parada Harahap, Indonesia Sekarang (Jakarta: Bulan Bintang, 1952), hlm. 141.

2 Said N., "Gusjigang dan Kesinambungan Budaya Sunan Kudus (Relevansinya Bagi Pendidikan Islam Berbasis Local Genius)", Jurnal Penelitian Islam Empirik, Vol 6, Nomor 2, JuliDesember, 2013.

3 Abdul Jalil, Spiritual Enterpreneurship (Studi Transformasi Spiritualitas Pengusaha Kudus), Disertasi Program Pascasarjana Institusi Agama Islam Negeri Sunan Ampel, Surabaya (Yogyakarta: LKIS, 2013). 198-200.
} 
mulai berubah pada pertengahan tahun 1912. Persaingan yang ketat menimbulkan rasa kebencian di antara kedua golongan ini. Sampai akhir tahun 1918, pedagang santri Kudus mengalami kemunduran ekonomi yang cukup signifikan. Ini berdampak pada memuncaknya rasa kebencian pedagangpedagang santri, khususnya para majikan haji.

Rasa kebencian yang memuncak akibat frustasi ekonomi dibarengi dengan peristiwa yang kental dengan propaganda agama pada Oktober 1918, mengakibatkan terjadinya suatu akibat destruktif. Masyarakat santri yang sudah termakan oleh propaganda agama seketika melakukan penyerangan dan menghancurkan tokok-toko dan pemukiman orang Cina. Penyerangan ini kental dengan kepentingan beberapa majikan santri dalam melanggengkan monopoli ekonomi di Kudus. Kerusuhan ini mengakibatkan banyak kerugian di pihak orang-orang Cina. Penyerangan terjadi dengan sistem pukul rata. Semua orang Cina baik yang totok atau peranakan dianggap musuh dan harus disingkirkan.

Setelah kerusuhan terjadi, tampillah beberapa pedagang santri seperti Nitisemito dan H.M. Muslich untuk mengambil tahta kuasa ekonomi rokok kretek di Kudus. Sebenarnya kedua tokoh ini tidak ikut serta di dalam kerusuhan, tetapi mereka mampu mengambil momentum emas untuk mengambil tongkat estafet kesuksesan orang Cina dalam menguasai perdagangan rokok kretek di Kudus. Mereka berdua merupakan contoh pribumi yang sukses di masa penjajahan kolonial Belanda. Mereka juga mampu bertindak mengembangkan sistem kerja industri secara efisien. Mereka mampu bertindak secara rasional dalam memanfaatkan peluang terhadap adanya sumber daya dan mampu bertahan terhadap kebijakan pemerintah kolonial Belanda yang kurang menguntungkan. Pada tahun 1932 dalam Staatsblad 1932 No. 517 secara resmi pemerintah memberlakukan pajak 20\% terhadap hasil tembakau berupa rokok kretek, sedangkan untuk rokok buatan mesin dikenakan pajak 50\%, untuk cerutu dibebankan pajak $40 \%$, dan $10 \%$ untuk rokok klobot buatan tangan. ${ }^{2}$

Kajian tentang sejarah dan perkembangan rokok kretek memang sudah banyak dilakukan di Indonesia. Baik dalam kajian lapangan maupun kajian kepustakaan. Bahkan tidak sedikit dari kajian itu yang sudah diterbitkan. Alex Nitisemito pernah menulis tentang Raja Kretek Nitisemito (1980). Dalam kajiannya lebih menitik beratkan kepada biografi, kedermawanan, dan sistem pemasaran rokok kretek di pabrik Nitisemito. Kajian ini menunjukkan betapa besar nama Nitisemito sebagai usahawan rokok di Kudus yang telah menunjukkan kemoderenan dalam sistem manajemen dan produksi. Alex juga memperlihatkan rasa nasionalisme Nitisemito pada masa perjuangan kemerdekaan dengan membantu mencukupi persediaan makanan para pejuang.

${ }^{4}$ Lance castles, Tingkah Laku Agama, Politik, dan Ekonomi di Jawa: Industri Rokok Kudus (Jakarta: Sinar Harapan, 1982), hlm. 56. 
Sementara itu Solichin Salam mengkaji tentang Kudus dan Sejarah Rokok Kretek (1983). Tulisan ini mendeskripsikan tentang perkembangan industri kretek di Kudus awal abad-20. Terdapat juga beberapa profil pedagang santri yang mendirikan pabrik rokok di Kudus. Ia juga menyoroti mengenai nasib buruh pabrik rokok. Meskipun kajian ini masih terkendala dengan sumbersumber sejarah, tetapi telah menyumbangkan literatur penting bagi kajian sejarah perdagangan rokok kretek di Kudus.

Selanjutnya kajian yang dilakukan Amen Budiman dan Onghokham, Kretek Lintas Sejarah dan Artinya bagi Pembangunan Bangsa dan Negara (1987). Tulisan ini mengkaji tentang sejarah penemuan, penyebaran tembakau di Eropa dan Indonesia. Dalam kajian ini juga membahas mengenai awal mula rokok kretek ditemukan di Indonesia. Amen dan Onghokham lebih menitikberatkan pada kajian ekonomi yang berfokus pada industri rokok. Bahwa adanya Industri rokok dapat membantu pemasukan keuangan negara dari masa kolonial Belanda sampai Indonesia meredeka.

Terakhir ada kajian yang ditulis Sri Margana, Kretek Indonesia dari Nasionalisme hingga Warisan Budaya (2014). Tulisan ini menganalisis mengenai aspek sosial-ekonomi dan budaya dari rokok kretek. Pertama, tulisan ini menarasikan historisitas mengenai kretek sebagai bagian penting untuk memaknai sejarah Indonesia. Kedua, tulisan ini mengungkap aspek sosialekonomi dan budaya dari kretek. Lebih tegas lagi Sri margana menjadikan berbagai aspek kretek yang sudah dikaji akan menjadikan kretek sebagai warisan budaya dan menjadi salah satu identitas Indonesia.

Sebagian besar penelitian yang telah dikemukakan mengkaji mengenai kretek sebagai warisan budaya Indonesia, sejarah perkembangan industri rokok di Indonesia, dan sumbangsihnya terhadap pembangunan bangsa. Bisa jadi akan ada kemiripan persoalan dan penghampiran teoritik antara penelitian ini dengan penelitian lain. Namun masih tampak ada kekurangan hasil penelitian tentang tindakan ekonomi yang dilakukan pedagang santri dalam industri rokok kretek yang mengambil latar wilayah di Kudus. Karena itu, akan diajukan tulisan yang mencakup tentang keadaan sosio-ekonomi di Kudus 1912-1918 masa awal persaingan, pedagang santri dalam mendirikan pabrik rokok kretek di Kudus, dan pola perilaku pedagang santri dalam mengembangkan pabrik rokok kretek di Kudus.

Guna memahami secara mendalam dan menyeluruh fenomena interaksi sosio-ekonomi pedagang santri dan Cina di Kudus, tindakan ekonomi, dan pola perilaku pedagang santri dalam mengembangkan pabrik rokok kretek di Kudus, tulisan ini memusatkan perhatian pada beberapa pertanyaan sebagai berikut, bagaimana keadaan sosio-ekonomi di Kudus di masa awal persaingan? Bagaimana pedagang santri dalam mendirikan pabrik rokok kretek di Kudus ? bagaimana pola-pola sosio-ekonomi pedagang santri dalam mengembangkan pabrik rokok kretek di Kudus? 
Berdasarkan deskripsi persoalan di atas, tulisan ini bertujuan memahami dinamika sosio-ekonomi, konflik ekonomi, tindakan ekonomi, pola perilaku, dan perkembangan pabrik rokok kretek yang terjadi akibat hubungan ekonomi masyarakat yang dilakukan pedagang santri. Tujuan tersebut bisa dikemukakan dalam beberapa garis besar pernyataan sebagai berikut: 1) menggambarkan konstruksi dan interaksi sosio-ekonomi yang terjadi antara pedagang santri dan Cina di Kudus, 2) menggambarkan Nitisemito dan H.M. Muslich dalam mendirikan pabrik rokok kretek, 3) mengenali pola-pola sosioekonomi dan tindakan ekonomi pedagang santri di Kudus.

\section{METODE PENELITIAN}

Peristiwa-peristiwa yang terjadi dalam penelitian ini akan dianalisis dengan pendekatan sosiologi ekonomi yang akan bertitik pada cara pandang terhadap beberapa konsep, yaitu konsep aktor dan tindakan ekonomi. Dalam memahami gejala historis yang serba kompleks, setiap penggambaran atau deskripsi menuntut adanya pendekatan yang memungkinkan penyaringan data yang di perlukan agar penelitian bisa dianalisa lebih mendalam. ${ }^{5}$

Sosiologi memandang konsep aktor sebagai kesatuan yang dikonstruksi secara sosial, artinya aktor dalam sosiologi tidak bisa dilihat sebagai individu itu sendiri, melainkan individu yang dikaitkan dengan individu-individu lainnya, baik secara perseorangan maupun dalam kelompok masyarakat. ${ }^{6}$ Konsep tindakan ekonomi mengasumsikan aktor mempunyai hak pilihan utama dalam tindakannya yang telah tersedia dan stabil. Tindakan yang dilakukan oleh aktor bertujuan untuk memaksimalkan pemanfaatan (individu) dan keuntungan (perusahaan). ${ }^{7}$ Tindakan ekonomi rasional mengedepankan individu dalam menjalankan kegiatan ekonomi dan mempertimbangkan interaksi atau relasi dengan individu lainnya untuk menunjang tujuan perkembangan. Tindakan ekonomi dapat dilihat sebagai suatu tindakan sosial sejauh tindakan tersebut memperhatikan tingkah laku orang lain. ${ }^{8}$

Mengenai konsep Santri dan Cina, Clifford Geertz mengatakan, konsep santri biasanya dipertautkan dengan elemen dagang orang Jawa, tradisi keagamaan santri tidak hanya terdiri dari pelaksanaan ritual dasar Islam secara cermat dan teratur, tetapi mencakup seluruh organisasi sosial, kedermawanan serta politik Islam. ${ }^{9}$ Pedagang antri yang dimaksudkan dalam penelitian ini adalah pribumi yang sudah haji. Konsep Cina yang dimaksud dalam penelitian ini adalah Cina totok (bukan peranakan) yaitu imigran yang datang setelah pergantian abad dan golongan Cina Peranakan yaitu orang Cina yang sudah

5 Sartono Kartodirjo, Pendekatan Ilmu Sosial dalam Metodologi Sejarah (Yogyakarta: Ombak, 2014), hlm. 4.

${ }^{6}$ Damsar, Pengantar Sosiologi Ekonomi (Jakarta: Kencana Prenada Media Group,

Cetakan Kedua, 2011), hlm. 41.

7Ibid., hlm. 42.

8Ibid., hlm. 44.

${ }^{9}$ Clifford Geertz, Agama Jawa; Abangan, Santri, Priyayi dalam Kebudayaan Jawa Terj. Aswab Mahasin dan Bur Rausanto (Jakarta: Komunitas Bambu, 2013), hlm. Xxx-xxxi). 
menikah dengan masyarakat lokal (pribumi). ${ }^{10}$ Menurut Masyhuri, Cina totok yang berada di Kudus merupakan kelompok suku Hok Kian, Hok Pek, dan Hakka. ${ }^{11}$

Penelitian ini menggunakan teori pertukaran-perilaku yang dikemukakan oleh George C. Homans. ${ }^{12}$ Teori ini didasarkan pada prinsip transaksi ekonomi. Orang menyediakan barang atau jasa dan sebagai imbalannya berharap mendapatkan barang atau jasa yang diinginkan. Manusia bekerja berharap mendapatkan hasil berupa uang atau timbal balik berupa relasi hubungan dalam kehidupan sehari-hari. Maka, manusia dalam memenuhi kebutuhan ekonomi tidak hanya mendapatkan materi, tetapi mendapatkan sahabat dalam menjalin hubungan ekonomi.

Ilmu ekonomi dapat menggambarkan hubungan-hubungan pertukaran dan sosiologi dapat menggambarkan struktur-struktur sosial di mana pertukaran itu terjadi. Dalam struktur dan lembaga-lembaga sosial terdapat individu-individu yang melakukan pertukaran barang baik berwujud materi maupun non-materi. Sistem pertukaran dan timbal balik dalam bidang sosiologi dan ekonomi sejatinya mempunyai kesamaan. Selalu ada pertukaran yang saling menguntungkan, apabila terjadi suatu kesepakatan kemitraan dalam bidang sosiologi maupun ekonomi. Maka dengan kuatnya jaringan akan mempermudah tujuan bersama dalam memajukan perekonomian.

\section{HASIL DAN PEMBAHASAN}

\section{Keadaan Sosio-Ekonomi di Kudus Masa Awal Persaingan}

Sebelum menerangkan menganai keadaan sosio-ekonomi, perlu di ketahui mengenai sejarah munculnya rokok kretek di Kudus. Munculnya rokok kretek tidak bisa dipisahkan dengan Jamhari yang berasal dari Kudus. Jamhari ${ }^{13}$ meracik rokok kretek pertama diperkirakan pada tahun $1880 \mathrm{M}$. Awalnya rokok temuan Jamhari oleh masyarakat Kudus disebut dengan "rokok cengkèh" karena terdapat campuran cengkih dalam rokok yang dibuatnya. Saat dihisap rokok tersebut mengeluarkan bunyi "krètèk-krètèk", maka jenis rokok ini disebut "rokok krètèk". ${ }^{14}$ Berawal dari racikan coba-coba dengan mencampurkan

${ }^{10}$ Achmad Habib, Konflik Antaretnik di Pedesaan pasang Surut Hubungan Cina-Jawa (Yogyakarta: LKIS, 2004), hlm. 10.

11Masyhuri, Bakar pecinan (Jakarta: Pensil-324, 2006), hlm. 25.

${ }^{12}$ Margaret M. Poloma, Sosiologi Kontemporer (Depok: PT Rajagrafindo Persada, cetakan 9, Januari 2013), hlm. 76.

13Penemu rokok kretek pertama dalam Lance Castles, Tingkah Laku Agama, yaitu H. Djasmari. Parada Harahap, Indonesia Sekarang, hlm. 145, mengatakan nama penemu rokok kretek pertama adalah H. Djamhari dan meninggal kira-kira tahun 1890, pernyataan Parada dikutip oleh Amen Budiman dan Onghokham, Rokok Kretek Lintas Sejarah dan Artinya Bagi Pembangunan Bangsa dan Negara. Mark hanusz, Kretek the Culture and Heritage of Indonesia's Clove Cigarettes, mengatakan nama penemu rokok kretek adalah H. Djamhari tahun 1880.

${ }^{14}$ Amen Budiman dan Onghokham, Rokok Kretek Lintas Sejarah dan Artinya Bagi Pembangunan Bangsa dan Negara (Kudus: PT. Djarum, 1987), hlm. 106. 
tembakau dengan cengkih yang digunakan untuk obat batuk, sesak napas, dan paru-paru.

Ide itu berdasar pada seringnya cengkih cair yang dioleskan ke dadanya sedikit-demi sedikit yang bisa meredakan penyakit asma yang diderita. Jamhari berpikiran bagaiamana kalau kandungan cengkeh dan tembakau ini dihisap sehingga bisa masuk langsung ke paru-parunya. Jamhari pun mengonsumsi rokok kretek setiap hari yang berdampak pada kesembuhan penyakitnya. Akibat manfaat yang terkandung di dalam rokok tersebut, masyarakat mulai tertarik pada rokok kretek buatannya. Permintaan masyarakat sekitar yang cukup banyak membuatnya berani mendirikan sebuah industri rumahan kecil yang diproyeksikan membuat rokok kretek.

Jamhari telah menciptakan maha karya besar yang masih bisa dinikmati oleh seluruh kalangan masyarakat Indonesia sampai sekarang. Jamhari tidak hanya orang yang pertama membuat rokok kretek, tetapi juga orang yang pertama mendirikan industri rumahan dalam produksi rokok kretek di Kudus. Produksi rokok kretek secara masif dipelopori oleh Haji Ilyas dan Haji Abdulrasul ${ }^{15}$ pada awal abad ke-20. Usaha ini kemudian dilanjutkan oleh para pengusaha lainnya. Animo terhadap rokok kretek tidak hanya terbatas pada wilayah Kudus, tetapi sudah menyebar ke kota-kota lain di Jawa Tengah dan Jawa Timur.

Pada awal tahun penemuannya, krètèk dijual ditoko-toko obat karena dianggap memiliki manfaat sebagai pengobatan untuk melonggarkan pernapasan. Salah satu tulisan di belakang kemasan salah satu merek rokok krètèk yang beredar dengan tulisan "kalau anda batuk dan isep ini rokok, maka batuk anda akan sembuh". ${ }^{16}$ Menurut Abhisam DM yang dikutip dari Edmund Gardener seorang praktisi pengobatan dari Inggris yang menulis The Triall of Tobacco, tembakau bermanfaat sebagai bahan pengobatan dengan petunjuk pemakaian yang benar dan bagi orang yang memakainya akan bermanfaat. ${ }^{17}$ Jika melihat manfaat yang terkandung dalam tembakau dan cengkih, tidak mengherankan apabila rokok krètèk bisa dijadikan sebagai obat.

Setelah menjamurnya pabrik rokok kretek rumahan (home industry) di Kudus, gejolak sosio-ekonomi mulai terjadi antar pedagang santri dan Cina. ${ }^{18}$ Banyaknya permintaan mengakibatkan santri-santri di Kudus mulai menggeluti bidang perdagangan rokok kretek selain berdagang kain. Orang Cina yang tinggal di Kudus juga mulai berdagang rokok kretek karena melihat banyaknya

15Solichin Salam, Kudus dan Sejarah Rokok Kretek (Kudus: PPRK, 1983), menyebutkan, sekitar tahun 1904, H.M. ilyas memproduksi rokok kretek secara massal, namun tidak ada keterangan merek rokok kretek yang dijualnya. Kemudian H.M. Abdulrasul menyusulnya dengan memproduksi rokok kretek dengan merek Nona Dansa.

${ }^{16}$ Abhisam DM, Hasriadi Ary, dan Miranda Harian, Membunuh Indonesia Konspirasi Global Penghancur Kretek (Jakarta: Penerbit Kata-kata, cetakan kedua, Maret 2012), hlm. 66-67.

17Ibid,. hlm. 34.

18Pada tahun 1900-an pesona rokok kretek sudah mendapatkan tempat dihati masyarakat Kudus. Bisnis pun di mulai dengan membuat industri rumahan guna mempermudah konsumen dalam mendapatkan rokok kretek tanpa harus melintingnya sendiri. 
permintaan konsumen. Pabrik-pabrik rokok kretek mulai banyak bermunculan seperti jamur yang tumbuh pada musim hujan.

Orang-orang Cina memiliki banyak akses untuk bersaing dengan pedagang santri Kudus. Mereka mempunyai kekuatan ekonomi-politik pada masa Hindia Belanda. Orang-orang Cina termasuk dalam strata kedua setelah orang Eropa dalam tingkatan stratifikasi sosial-politik Belanda. Ambisi orangorang Cina untuk setara dengan orang Eropa menjadikannya berusaha untuk menguasai seluruh bidang kehidupan, terutama bidang perekonomian. Bangsa Cina merupakan golongan pendatang orang asing yang merasa superior dengan modal besar. Mereka sedikit demi sedikit mampu monopoli perdagangan rokok kretek di Kudus. Akibatnya terjadi persaingan antara pedagang santri dan Cina yang nantinya menimbulkan potensi-potensi kebencian yang meningkat.

Orang Cina mulai mengalami kemajuan dalam hal perdagangan pada pertengahan tahun 1912. ${ }^{19}$ Kesenjangan sosio-ekonomi yang terjadi antara pedagang santri dengan pedagang Cina mengakibatkan adanya sebuah persaingan yang ketat antara kedua belah pihak. Perdagangan yang awalnya dikuasai golongan elite santri yaitu para haji dan Kiai, secara lambat berpindah ke penguasaan pedagang Cina.

Dominasi negara atas rakyat menjadikan ketidakberdayaan santri dalam menghadapi persaingan ini. Ketimpangan ekonomi banyak menimbulkan frustasi di kalangan pedagang santri khususnya buruh pekerja. Tidak adanya fasilitator yang menjembatani komunikasi dua arah dengan negara, akan mengakibatkan situasi bisa menjadi semakin memburuk yang bisa menimbulkan konflik yang berkepanjangan. Orang Cina sebagai orang asing telah menjadi kekuatan yang berbahaya bagi kelangsungan hidup pedagang santri di Kudus.

Diskriminasi yang dilakukan oleh pemerintah Belanda terhadap pribumi sebagai kasta bawah, membuat orang Cina lebih mudah untuk melakukan dominasi ekonomi-politik di Kudus. Orang Cina diberikan hak istimewa untuk memonopoli perdagangan. Hal ini yang membuat banyak terjadi goncangan sosial yang tejadi di Kudus. Meningkatnya kendali ekonomi oleh majikan Cina menimbulkan rasa tersingkir dan frustasi mendalam dari majikan santri. Orang Cina dianggap mengganggu tatanan tradisional yang telah mapan di masyarakat Kudus. Interaksi sosial yang terjalin antara kedua etnis ini selalu bermuara kepada persaingan ekonomi. Orang Cina dianggap sebagai pendatang yang datang dengan banyak kepentingan khususnya ekonomi. Orang-orang Cina juga sering dianggap menggeser jaringan perdagangan lokal. Tidak dapat dipungkiri bahwa pedagang Cina biasanya lebih kompetitif dalam sektor perdagangan dibandingkan dengan penduduk lokal. 
Pada saat tertentu pedagang Cina lebih mampu memberikan pinjaman uang kepada para buruh pabriknya (pribumi). Hal ini dilakukan untuk mengikat buruh-buruhnya agar bisa mengabdi lebih lama karena masih mempunyai tanggungjawab membayar hutang. Para majikan Cina juga mampu menjamin para buruh pekerja dengan kemakmuran. ${ }^{20}$ Hal ini merupakan praktik perbudakan yang dilanggengkan pada masa kolonial. Hutang akan mengikat buruh menjadi pekerja selamanya di dalam perusahaan orang-orang Cina. Meskipun mereka diberi upah yang cukup, namun upah mereka hanya cukup menutup hutang terhadap majikannya dan membayar hutang rentenir Cina yang telah dipinjam terdahulu berikut bunganya.

Pada pertengahan tahun 1912 perdagangan rokok kretek mengalami kemajuan dengan pesat. ${ }^{21}$ Persaingan ekonomi antara santri dengan Cina mulai terasa sengit. Benih-benih kebencian mulai terasa, meskipun belum terlihat ke permukaan. Kemajuan perdagangan orang-orang Cina membuat pedagang santri merasa tidak senang. Kemajuan-kemajuan ini membuat santri semakin terdesak. Awal dasawarsa abad ke-20 menjadi titik pijak kebencian-kebencian majikan santri terhadap majikan Cina. Pedagang santri kalah bersaing dengan produk-produk rokok pedagang Cina. Kemajuan pedagang Cina berakibat pada menurunnya produksi rokok kretek pedagang santri. Para pedagang Cina mampu memainkan harga pasar untuk mendapatkan perhatian konsumen. Mereka juga banyak mengambil buruh terampil dari majikan santri dengan penawaran gaji yang lebih besar. Praktik-praktik curang mulai diperlihatkan oleh pedagang Cina dalam menguasai produksi dan pemasaran rokok kretek.

Para buruh yang bekerja pada majikan santri juga bekerja kepada majikan Cina di malam harinya. Keadaan ekonomi memaksa buruh-buruh ini bekerja malam untuk menambah penghasilan untuk memenuhi kehidupan sehari-hari dan untuk menabung saat lebaran datang. ${ }^{22}$ Para buruh ini melakukan kerja malam juga untuk membayar hutang kepada rentenir Cina. Pagi sampai sore mereka bekerja dengan majikan santri, malamnya bekerja dengan majikan Cina yang mulai kebanjiran pesanan. Pada tahun 1912-an pedagang Cina banyak mendapat pesanan dari berbagai tempat, sehingga banyak memerlukan buruh untuk memenuhi pesanan. ${ }^{23}$ Buruh yang bekerja malam tidak hanya terdapat di kudus tua saja, tetapi juga pemukiman Cina yang dekat pasar. ${ }^{24}$

Rasa kebencian terhadap persoalan ekonomi secara lambat berkembang dan bercampur dengan kebencian agama. Ada sebuah peristiwa yang melatabelakangi memuncaknya amarah majikan santri dan buruh pribumi atas orang-orang Cina. Peristiwa arak-arakan Toa Pek Kong yang dilakukan orangorang Cina untuk mengusir roh jahat yang membawa wabah penyakit flu

\footnotetext{
${ }^{20}$ Castles, Tingkah Laku, hlm. 143.

${ }^{21} \mathrm{Kim}$, Peroesoehan, hlm. 11

22Ibid., hlm. 12.

${ }^{23}$ Ibid., hlm. 14.

24Ibid., hlm. 23.
} 
Spanyol yang sedang menyerang kota, sedang melewati depan masjid Menara Kudus pada Oktober 1918. ${ }^{25}$ Saat itu situasi sedang ramai di Masjid Menara karena masyarakat sedang melakukan pemugaran masjid. Dalam arak-arakan tersebut terlihat satu orang Cina menggunakan pakaian seperti haji yang sedang bermain dengan wanita nakal. Penampilan orang Cina itu langsung mendapat reaksi keras dari umat Islam. Penampilan itu dianggap sebagai langkah provokatif yang dilakukan orang-orang Cina terhadap umat Islam. Tentu kejadian itu menimbulkan banyak reaksi dari masyarakat karena sudah menyerang ranah privasi keagamaan umat Islam.

Datang kemudian santri-santri yang mendorong gerobak berisi batu dari sungai gelis yang berpapasan dengan arak-arakan. Melihat adanya kejanggalan dengan pakaian yang dikenakan oleh orang Cina yang berpakaian haji, seketika Sanusi menabrakkan grobaknya ke arah pedati yang dinaiki orang Cina itu. ${ }^{26}$ Tabrakan itu mengakibatkan keributan antara santri-santri yang mendrong gerobak dengan orang-orang Cina yang mengikuti arak-arakan. ${ }^{27}$ Keributan kemudian menyebar dengan melibatkan seluruh masyarakat yang sedang memperbaiki masjid dan orang-orang Islam yang sedang menyekasikan kejadian itu. ${ }^{28}$

Sebagian besar kerumunan santri melempari orang-orang Cina dengan batu yang ada di masjid. Kekacauan pun terjadi semakin besar. Banyak orangorang Cina menyelamatkan diri menuju arah selatan ke arah simpang empat dan sebagian lagi meninggalkan keributan dan berlari ke arah Timur. ${ }^{29}$ Umat Islam mendesak orang-orang Cina untuk mundur dan segera meninggalkan lingkungan masjid menara. Polisi yang datang kemudian berusaha meredamkan keributan. Mereka mencegah santri-santri yang marah untuk mengejar orang-orang Cina. Polisi juga mengintruksikan orang-orang Cina untuk segera mundur. Tidak ada laporan yang mencatat mengenai korban luka dan kerusakan yang terjadi setelah terjadinya pertikaian.

Setelah peristiwa itu, orang-orang Cina telah dianggap etnis yang merusak tatanan kedamaian di Kudus. Rasa kebencian bermotif ekonomi sekarang semakin kuat dengan perpaduan agama. Propaganda-propaganda akan mudah dilakukan apabila diikuiti dengan propaganda agama. Sampai peristiwa keributan itu berakhir, belum ada langkah dialogis yang dilakukan kedua etnis melalui perwakilan pemimpinnya. Belum ada juga dialog yang difasilitasi oleh pemerintah untuk meredam terjadinya konflik kembali. Hanya ada pertemuan pemerintah dengan beberapa anggota Sarekat Islam (SI) Kudus pada 31 Oktober 1918 untuk melakukan pencegahan terjadinya konflik.

${ }^{25}$ Bijlagen Van Het Verslag Der Handelingen Van De Tweede Kamer Der Staten Generaal 1919-1920, hlm. 46-47.

${ }^{26}$ Masyhuri, Bakar, hlm. 65.

27Bijlagen Van Het Verslag Der Handelingen Van De Tweede Kamer Der Staten Generaal 1919-1920, hlm. 46-47.

${ }^{28}$ Masyhuri, Bakar, hlm. 66.

${ }^{29}$ Ibid. 
Pertikaian pertama yang terjadi ternyata menjadikan memuncaknya benih-benih konflik baru. Rasa ingin menyingkirkan satu etnis karena sentimen ekonomi dan agama mulai memuncak. Majikan santri yang mempunyai banyak kepentingan ekonomi menjadikan kebencian umat Islam Kudus kepada orang Cina dengan seruan propaganda agama sebagai lecutan provokatif untuk melakukan penyerangan.

Sumber-sumber konflik antara pendatang dengan masyarakat lokal sering disebabkan oleh kepentingan-kepentingan ekonomi. ${ }^{30}$ Konflik antar etnis memang sering terjadi karena motivasi ekonomi yang dipadukan dengan motif agama sehingga propaganda yang dilakukan akan menjadi lebih kuat. Ketidaksetaraan ekonomi antara orang Cina secara umum dan santri sering menjadi bahan bakar konflik, tetapi akan menjadi lebih buruk jika digabungkan dengan perbedaan dalam identitas agama.

Dialog yang terjadi anatara anggota SI Kudus dan pemerintah ternyata belum bisa menjembatani resolusi konflik antara kedua etnis ini. Setelah paginya dilakukan proses dialog dengan pemerintah, penyerangan ke pemukiman orang-orang Cina terjadi pada malam hari tanggal 31 Oktober 1918. Propaganda-propaganda banyak dilakukan oleh majikan santri yaitu haji-haji yang mayoritas merupakan anggota SI Kudus. Mereka melakukan propaganda untuk menumbuhkan semangat perlawanan kepada orang Cina atau anti-Cina. Hal ini merupakan efek domino dari persaingan pribumi dengan Cina yang bermotif ekonomi dibeberapa daerah di Indonesia.

Penyerangan umat Islam ke pemukiman orang Cina juga melibatkan preman-preman dari luar kota Kudus. Kekerasan biasanya bisa dijelaskan dengan kebiasaan menggunakan kekuatan-kekuatan luar pengadilan, seperti geng atau berandal. ${ }^{31}$ Situasi ketegangan juga sangat kental dengan motif-motif sosio-ekonomi. Terbukti bahwa dalam penyerangan tersebut banyak toko-toko, barang-barang, dan juga rumah-rumah yang dirusak dan dibakar oleh kelompok santri. ${ }^{32}$ Kejengkelan terhadap orang Cina menjelaskan mengapa toko, barang, dan rumah orang Cina dihancurkan dan dijadikan sebagai sasaran.

Penguasaan ekonomi secara luas telah menyulut kebencian dan kemarahan masyarakat lokal terhadap orang Cina yang diberikan beberapa hak monopoli ekonomi oleh pemerintah Belanda. Meskipun ada motif agama dalam penyerangan tersebut, tetapi itu dipandang sebagai faktor pelengkap kuatnya kerusuhan.

30Jacques Bertrand, Nasionalisme dan Konflik Etnis di Indonesia, terj. Achmad Munjid (Yogyakarta, Ombak, 2012), hlm. 151.

31Ibid., hlm. 199

32Masyhuri, bakar, hlm. 73. 


\section{Pedagang Santri dalam Merintis Berdirinya Pabrik Kretek di Kudus}

Setelah mengalami kegagalan pada tahun 1912 sampai 1920. Pada tahun-tahun berikutnya pedagang santri mulai merintis usahanya kembali. Beberapa pedagang santri seperti Nitisemito dan H.M. Muslich akan penulis lihat lebih jauh karena menjadi pedagang yang cukup sukses di Kudus pada tahun 1930an. Dipihak lain, akibat dari kerusuhan yang terjadi Oktober 1918, orang-orang Cina masih belum bisa menguasai ekonomi di Kudus. Mereka telah mengalami kerugian cukup besar karena aset-aset berharga mereka sudah rusak dan hilang terbakar. Beberapa dari mereka berpindah ke daerah Kudus Timur, Semarang, dan beberapa orang lainnya belum berani kembali ke Kudus.

Berdirinya pabrik rokok kretek di Kudus yang dimiliki santri mulai mengalami perkembangan setelah terjadinya kerusuhan. Data yang dilihat dari Amen Budiman dan Onghokham, pada tahun 1934 ada 152 buah pabrik rokok yang berdiri di Kudus yang rata-rata mempunyai 2000 karyawan. ${ }^{33}$ Apabila dijumlahkan ada 304.000 lebih orang yang bekerja di pabrik rokok, dimana pabrik-pabrik tersebut di dominasi pedagang santri. Kemungkinan pada tahuntahun berikutnya jumlah pabrik rokok kretek mengalami peningkatan setelah stabilnya harga dan impor cengkeh.

Tokoh-tokoh pedagang santri merupakan haji-haji yang berperan sebagai pengusaha kretek. ${ }^{34}$ Golongan pengusaha santri inilah yang memainkan peran dalam perkembangan perekonomian lokal dan organisasi Islam di Kudus. Dalam laporan Departemen Ekonomi tahun 1930, dari 48 orang pedagang kretek santri 18 orang anggotanya pendukung Nahdatul Ulama, 16 orang anggotanya pendukung Muhammadiyah, dan 8 orang lainnya bersikap netral, dimana satu orang masuk dalam anggota organisasi yang lebih kecil, yaitu PSII, satu lainnya tidak mendukung organisasi manapun, dan 6 orang sisanya membantu kedua organisasi tersebut dalam hal finansial. ${ }^{35}$ Dukungan yang dilakukan oleh pengusaha santri dalam membangun organisasi Nahdatul Ulama dan Muhammadiyah, membuat gerakan ini menjadi lebih progresif dengan mengambangkan sekolah-sekolah, membangun rumah sakit, dan rumah miskin. ${ }^{36}$

Beberapa tokoh-tokoh pedagang santri pendiri pabrik rokok kretek di Kudus adalah sebagai berikut;

\section{a) Nitisemito (1863-1953)}

Nitisemito lahir di Kudus pada tahun 1863. Ia mempunyai nama kecil dengan panggilan Roesdi, tetapi setelah beranjak dewasa namanya diganti menjadi Nitisemito. Ia merupakan pemuda yang ulet dan gemar mendekatkan diri kepada Allah. Nitisemito merupakan putra sulung dari

${ }^{33}$ Budiman, Kretek Lintas Sejarah, hlm. 124.

34Sri Margana, Kretek Indonesia dari Nasionalisme Hingga Warisan Budaya (Yogyakarta: Jurusan Sejarah Fakultas Ilmu Budaya Universitas Gajah Mada dan PUSKINDO, 2014), hlm. 176.

${ }^{35}$ Ibid., hlm. 108-109.

36Ibid., hlm. 39. 
dua bersaudara. Ayahnya bernama H. Soelaiman dan ibunya bernama Markamah. Ayahnya bekerja sebagai Kepala Desa Janggalan Kudus. ${ }^{37}$ Sejak awal Nitisemito diharapkan oleh ayahnya bekerja menjadi perangkat desa. Keinginan ayahnya di mulai dengan menjadikannya sebagai Carik atau Sekretaris Desa Janggalan Kudus. ${ }^{38}$

Namun, pekerjaan sebagai perangkat desa tidak sesuai dengan keinginanya. Pada usia 17 tahun dengan keinginan untuk menjadi pedagang yang sukses, ia kemudian merantau ke Malang Jawa Timur untuk berdagang. Dalam rangka memantabkan hati untuk melangkahkan kaki menuju kesuksesan dilakukan pergantian nama dari Roesdi menjadi Nitisemito. ${ }^{39}$ Setelah beberapa tahun bekerja di Malang dengan pengalaman yang cukup, ia mendirikan industri rumahan berupa konveksi. Industrinya ini tidak terlalu besar karena modal yang didapatkannya dari bekerja menjadi buruh jahit tidak begitu banyak. Setelah berjalan beberapa waktu, usahanya ini mengalami kemunduran. Nitisemito terlilit hutang yang menjadikan usahanya bangkrut. ${ }^{40}$

Setelah beberapa kali mengalami kegagalan mendirikan usaha, akhirnya ia kembali ke Kudus. Nitisemito kemudian berjualan tembakau dan menjualnya ke warung-warung di Kudus. Nasilah merupakan salah satu yang berlangganan tembakau Nitisemito. Sembari berjualan makanan, Nasilah juga berjualan rokok klobot dengan melinting sendiri. Tembakau yang dijual Nitisemito merupakan salah satu tembakau terbaik untuk diracik menjadi rokok klobot.

Pertemuan Nitisemito dengan Nasilah yang awalnya sebagai rekan bisnis, akhirnya berbuah pernikahan pada tahun 1894. ${ }^{41}$ Setelah menikah, Nitisemito dan Nasilah memulai usaha penjualan rokok klobot yang terkenal enak dan harum. Hasil produksi rokoknya dijual ke warung-warung yang

37Dalam buku Margana, Kretek Indonesia, mengatakan posisi yang di jabat oleh ayah Nitisemito merupakan permintaan warga desa setelah usaha perdagangannya bangkrut.

${ }^{38}$ Keterangan Nitisemito pernah menjadi Sekretaris Desa Janggalan Kudus peneliti temukan dalam arsip yang disarikan dari buku Der Kretek Koning M. Nitisemito, lampiran 17, hlm. 120. Untuk melancarkan keinginan ayahnya supaya Nitisemito mau meneruskan jabatannya, akhirnya Nitisemito diajari membaca dan menulis. Amen Budiman dan Onghokham, Rokok Kretek, menyebutkan bahwa Nitisemito merupakan seorang pengusaha yang benar-benar seorang tuna aksara, sama sekali tidak bisa membaca dan menulis, hlm. 128. Apabila seorang Nitisemito seorang tuna aksara, maka akan sulit ia bisa menjadi seorang sekretaris desa yang mempunyai tugas membantu Kepala Desa dalam menyelenggarakan program desa dan tugas sekretaris sangat kental sekali dengan tulis-menulis.

39Zaman dahulu pergantian nama bagi masyarakat Jawa sangat lumrah dilakukan. Pergantian nama tersebut biasanya dilakukan saat seseorang telah menginjak usia dewasa dan pergantian nama juga dilakukan setelah menunaikan ibadah haji bagi seorang muslim. Ketika seseorang sudah menginjak usia dewasa akan ada perubahan nama, begitupun juga sesudah menunaikan ibadah haji akan ada perubahan nama baru, diharapkan dengan nama baru tersebut akan membuat kehidupan seseorang lebih baik dari sebelumnya.

${ }^{40}$ Alex S. Nitisemito, Raja Kretek Nitisemito (Kudus: t.p, 1980), hlm. 17-18.

${ }^{41}$ Nitisemito dijodohkan oleh orangtuanya dengan Nasilah, perempuan asal Desa Singocandi, Kudus. 
berada di Kudus, Semarang, Kendal, Ambarawa, dan Mojokerto dengan mengandalkan bantuan adiknya, yaitu Atmosemito yang berperan sebagai distributor. ${ }^{42}$

Perusahaan Nitisemito yang awalnya hanya industri rumahan kecil kemudian berkembang menjadi industri yang besar dan telah terdaftar di Gedeponeerd $^{43}$ tanggal 18 Februari 1908 dengan nomor 4642. Nitisemito pertama kali menjual produk rokok kreteknya menggunakan pembungkus kertas koran seharga harga 2.5 sen seikat yang berisi 25 batang rokok kretek ukuran kecil, dan harga 3 sen seikat yang berisi 25 batang rokok kretek ukuran besar. ${ }^{44}$ Kemasan rokok kretek awalnya masih sangat sederhana, berbeda dengan sekarang yang banyak menggunakan degradasi warna yang bermacam untuk menarik konsumen.

Nitisesmito merupakan sosok pedagang yang berpikiran maju pada masanya. Ia mempunyai etos kerja yang tinggi dengan memanfaatkan segala upaya untuk mengembangkan perdagangannya. Salah satunya menggunakan media promosi modern dengan menggunakan poster dan promosi berhadiah. Hubungan interaksi juga selalu terjalin baik dengan karyawan, rekan bisnis, maupun golongan pejabat. Nitisemito merupakan sosok inspiratif kemoderenan berpikir dalam bidang ekonomi di atas keterbatasan yang ada.

\section{b) H.M Muslich (1883-1956)}

H.M. Muslich lahir pada tahun 1883 di Desa Burgoro yaitu salah satu daerah yang dekat dengan gunung Muria. ${ }^{45}$ Nama kecil yang diberikan oleh ayahnya yaitu multazam. Multazam semenjak kecil telah belajar di pesantren. Setelah dari pesantren, ia bekerja kepada Rahmat yaitu salah seorang kakak iparnya yang cukup terpandang di desanya. Namun setelah bekerja beberapa lama, gaji yang didapatkan tidak sebanding dengan pekerjaan yang dilakukan. Keadaan tersebut membuatnya keluar dari pekerjaannya. Ia kemudian merantau untuk mendapatkan penghasilan lebih besar sembari mencari pengalaman hidup di perantauan.

Multazam memutuskan untuk merantau ke Laweyan, Solo. Sesampainya disana ia bekerja kepada Mbok Wiryo salah seorang penjual batik. Multazam yang sudah bekerja menjaga toko selama beberapa tahun dengan keuletan dan kejujurannya, akhirnya mendapat kepercayaan untuk

${ }^{42}$ Margana, Kretek Indonesia, hlm. 60.

${ }^{43}$ Tulisan yang biasanya terdapat pada sebuah merek dagang sebagai tanda bahwa merek tersebut sudah terdaftar di lembaga perindustrian negara untuk jaminan hak pemakaian merek tersebut.

${ }^{44}$ Arsip keluarga Nitisemito yang disarikan dari buku Der Kretek Koning M. Nitisemito (Badan Arsip dan Perpustakaan Provinsi Jawa Tengah pada 2 Maret 2016).

45Salam, Kudus, hlm. 33. 
menjadi distributor batik yang kesemua barangnya diambil dari toko Mbok Wiryo.

Ada hal menarik yang dilakukan Multazam ketika mengirimkan batik kepada langganannya. Ia selalu membawa rokok kretek buatan istrinya untuk diperjual-belikan kepada langganan-langganannya. Hubungan perdagangan yang dijalin tidak hanya dalam jual beli batik, tetapi melebar pada jual beli rokok kretek. Multazam juga menjual dan menitipkan rokoknya di warung klontongan yang dimiliki pedagang Cina bernama Ekkie Tan Khe Tjie. Ia juga menitipkan rokoknya ke pedagang es dorong di Songoyudan, Surabaya.

Multazam membuka pabrik rokok kretek sekitar tahun 1914. Ia pertama kali menggunakan merek De Klauw (kuku lima). Ia mendirikan pabrik seluas 2.500 x 50 meter yang terletak di Desa Langgardalem, Kudus. Setelah pabriknya berdiri, sedikit demi sedikit usahanya mulai berkembang menjadi industri cukup besar. H.M Muslich mengganti merek rokok kretek yang awalnya De Klauw menjadi "Tebu dan Cengkeh". Alasan pergantian ini diambil karena merek rokoknya yang pertama kurang menjual. Ternyata penggantian merek ini berbuah manis. Hasil dari penjualan rokok kretek membuatnya mampu menunaikan ibadah haji dan berlanjut untuk kedua kalinya dilaksanakan tahun 1939. Setelah pulang dari haji nama aslinya yaitu Multazam diganti menjadi H.M Muslich.

Pabrik rokok kretek H.M. Muslich merupakan salah satu pabrik yang terbilang cukup besar yang berdiri di Kudus. Parada Harahap menyamakan pabrik tersebut seperti gedung Bank Nasional Indonesia di Surabaya yang semuanya serba modern. ${ }^{46}$ Ketika berkunjung ke pabrik H.M. Muslich, Parada melihat semua ruangan tempat kerja dan proses pembuatan kretek sampai pengemasannya yang sangat teratur. Semua pekerjaan dilakukan oleh orang-orang pribumi, dari majikan sampai buruhnya semua orang Indonesia asli. Pada tahun 1935-1939 saat produksi rokok kretek mencapai puncaknya, dalam waktu satu bulan keuntungannya bisa dibelikan 5 buah mobil yang masing-masing berharga 2.300 gulden dengan merek Chryster. ${ }^{47}$

Pabrik H.M. Muslich pernah mendapat kunjungan kehormatan dari Gubernur Jenderal Belanda G.G. Jhr. Mr. Tjarda van Starkenburg Stachouwer bersama istrinya pada tanggal 19 Maret 1939.48 Kunjungan tersebut dilakukan karena kekaguman Gubernur Jenderal Belanda terhadap pabrik Tebu dan Cengkeh yang membelanjakan uangnya untuk membeli banderol cukai mencapai seperempat juta gulden. ${ }^{49}$

${ }^{46}$ Harahap, Indonesia, hlm. 151.

47Salam, Kudus, hlm. 34.

${ }^{48}$ Harahap, Indonesia, hlm. 152.

${ }^{49}$ Muhammad Wasith Albar, "Sejarah Perkembangan Pengusaha Pribumi dan NonPribumi Industri Kretek di Kudus 1908-1975” dalam ICSSIS, 2011, hlm. 260. 


\section{Pola Sosio-ekonomi Pedagang Santri dalam mengembangan Industri Kretek di Kudus tahun 1930}

Perkembangan industri kretek yang didirikan oleh santri terjadi karena dipengaruhi oleh faktor pengusaha itu sendiri, yang mampu menjadi aktor dalam sebuah tindakan ekonomi dan mampu memainkan peran pentingnya dalam perkembangan sebuah perusahaan. Tindakan ekonomi rasional diambil oleh pedagang-pedagang ini dalam mengambilan tenaga kerja terdekat dari pusat produksi yang memberi manfaat untuk memangkas biaya pengeluaran operasional perusahaan. Kebanyakan dari tenaga kerja yang dipakai adalah para wanita atau ibu rumah tangga.

Gerak sejarah manusia pasti akan menemui suatu tantangan dalam perjalanannya. Nitisemito dan H.M. Muslich sudah mendapat masalah pada awal pembangunan industri kretek. Permasalahannya mengenai tempat-tempat para pekerja yang terlalu kecil, meskipun tempat produksi selalu diperluas dengan membeli beberapa rumah terdekat. ${ }^{50}$ Apabila melakukan pembangunan tempat pekerja baru yang lebih besar, tentunya akan mengeluarkan biaya yang lebih besar.

Dalam memecahkan masalah ini pada tahun 1920 dipakailah sistem baru $^{51}$ yang pertama kali diperkenalkan oleh Nitisemito. Sistem tersebut dipakai Nitisemito dalam perusahaannya sebagai langkah revolusi supaya membuat pabrik rokoknya tidak mengalami kemunduran. Mereka memanfaatkan abon 52 sebagai tenaga pemborong dalam pembuatan rokok kretek tanpa harus menyediakan tempat untuk pekerja.

Tata cara pelaksanaan sistem ini, yaitu para abon yang sudah ditunjuk oleh pengusaha, pergi ke pabrik mengambil racikan cengkih dan tembakau yang sudah dicampur dengan saus, kemudian dibawa ke desa-desa dan di distribusikan ke pekerja rumahan bawahan para abon atau biasa disebut kernet. ${ }^{53}$ Seminggu kemudian setelah rokok kretek yang digulung selesai, para abon kembali mengumpulkan hasil gulungan rokok kretek yang nantinya dibawa kembali ke pabrik. Setelah rokok kretek disortir dan diterima, para abon mendapatkan upah sesuai dengan banyaknya batang rokok yang sudah dibuat per seribu batang.

Beban upah kernet, semuanya diserahkan dan diatur oleh abon yang berperan sebagai perantara antara pekerja dan manajemen pabrik.

50Pada awal berdirinya industri kretek di Kudus, pabrik yang dipakai untuk produksi dilakukan dalam rumah, berbeda dengan pabrik zaman sekarang yang berbentuk bangunan besar dan dapat menampung banyak karyawan didalamnya.

${ }^{51}$ Sistem baru tersebut adalah sistem abon yang banyak dipakai dalam industri kretek pada waktu itu.

${ }^{52}$ Kata abon berasal dari bahasa Belanda "Abonemen" yang biasa diartikan dengan 'langganan', yang kemudian disingkat menjadi "Abon", dalam Mark Hanusz, Kretek the Culture and Heritage of Indonesia's Clove Cigarettes (Jakarta: Equinox Publishing, 2003), hlm. 38.

${ }^{53}$ Kernet merupakan pembantu abon yang bertugas menggulung rokok kretek dengan bahan-bahan yang sudah disediakan oleh pabrik. 
Pemberlakuan sistem ini memungkinkan desa-desa terjauh di Kudus tanpa kesulitan bisa ikut dalam proses produksi dan usahawan-usahawan muslim tidak perlu memikirkan mendirikan pabrik baru. Penerapan sistem abon membuat Nitisemito dan H.M. Muslich dapat meningkatkan sistem produksi tanpa harus menyediakan tempat kerja yang lebih besar.

Alasan utama mengapa sistem abon terbukti begitu sukses adalah perusahaan baru yang tidak memiliki fasilitas atau sumber daya modal untuk karyawan dengan jumlah besar yang dibutuhkan untuk proses kerja, bisa membangun industri sendiri dan dapat mencapai keberhasilan pemasaran produk mereka. Semua ini juga menghilangkan risiko biaya tenaga kerja dan pabrik rokok kretek tidak perlu khawatir tentang memberikan kesejahteraan sosial bagi para pekerja mereka karena semua tanggungjawab sudah diserahkan kepada abon. Meskipun sistem ini mulai ditinggalkan pada tahun 1930.54

Menurut Sri Margana yang dikutip dari Lance Castles, pada abad ke-20 kota Kudus mempunyai karakteristik yang berbeda dengan kota-kota umumnya di indoensia, dimana sektor ekonomi non-Belanda dikuasai oleh Cina dan Arab, tetapi di Kudus golongan tersebut tersingkir dari ranah ekonomi oleh santri. ${ }^{55}$ Pedagang-pedagang santri ini merupakan seorang self mademan yang berhasil dengan kemampuan dan pengetahuannya sendiri dalam bidang industri. Kesuksesan yang didapatkan atas kerja keras dan kecerdasan dalam merintis suatu pabrik dari kecil sampai menjadi pabrik yang besar. Secara umum perilaku hidup yang selalu dipegang pedagang santri ini adalah selalu menengok kebelakang dan belajar kepada semua kejadian yang sudah terjadi. Falsafah hidup belajar dari sejarah orang terdahulu perlu dilakukan untuk menatap masa depan yang lebih cerah dan berkemajuan.

Melalui industri kretek yang ditekuni dengan semangat bekerja keras, ulet, dan hemat menjadikan santri-santri ini secara bertahap dapat mengumpulkan modal untuk memperbesar pabriknya. Seorang pedagang pribumi yang berasal dari kelas bawah dari golongan santri, karena kerja keras dan upayanya dengan mengembangkan suatu konsolidasi sosial akhirnya dapat menikmati gaya hidup serta lepas dari rasa penderitaan sebagai warga jajahan. Pedagang santri ini juga sebagai orang yang memberi pekerjaan kepada sesama warga jajahan. Mereka berubah menjadi golongan borjuis santri baru di masa kolonial Belanda.

Pedagang santri mampu mengembangkan kemampuan, sanggup memahami dan mengelola kesadaran diri untuk dapat meningkatkan kualitas hidup. Santri ini juga mampu mengembangkan nilai-nilai moralitas perdagangan yang sarat dengan nilai luhur budaya. Pedagang santri ini juga

${ }^{54}$ Naiknya harga cengkeh dari f. 75 ke f. 160 membuat pedagang santri menurunkan upah minimum pekerja abon dan kernet per seribu batang. Keadaan ini membuat pekerja tidak senang dan mensabotase racikan rokok kretek dengan cengkih kualitas rendah. Beberapa kecuarangan ini mengakibatkan sistem abon mulai ditinggalkan oleh pabrik-pabrik rokok di Kudus.

55Margana, Kretek Indonesia, hlm. 139. 
mempunyai interaksi sosial yang baik untuk menjalin hubungan kemitraan kepada pedagang lain. Hal ini dilakukan dengan harapan mendapat keuntungan secara ekonomi dan sosial.

Sistem pemasaran menjadi penting untuk menunjang perkembangan industri ini. Nitisemito mempunyai cara tersendiri dalam memasarkan produk rokok kretek dengan menggunakan strategi promosi yang sudah terbilang modern. Ia banyak memanfaatkan teknologi seperti menyebar pamflet dari udara dengan menyewa pesawat terbang dengan harga yang tidak murah. Promosi juga dilakukan dengan menempelkan pamflet di penjual es keliling. Sungguh pemikiran berkemajuan dengan menerapkan strategi promosi yang belum banyak perusahaan lain berpikiran untuk melakukan hal tersebut.

Media promosi juga dilakukan dengan menjadi sponsor utama kesenian sandiwara keliling dengan memasang background panggung bergambar Bal Tiga dan semua alat musik yang dipakai bergambarkan merek Bal Tiga. Perusahaan juga memberikan promosi dengan pemberitahuan yang ditulis di belakang bungkus rokok Bal Tiga untuk menyimpan bungkus rokok tersebut. Ketika sudah terkumpul dengan jumlah tertentu nantinya bisa ditukarkan dengan hadiah seperti, sepeda, jam dinding, mangkuk, cangkir, dan piring.

Pada tahun 1930-an mulailah berkembang industri rokok besar di kalangan santri. Nitisemito mampu mendirikan pabrik besar di Desa Jati Kudus seluas 6 hektar yang dapat menampung 15.000 pekerja dengan produksi rokok kretek mencapai 12 juta batang setiap harinya. ${ }^{56}$ Rokok kretek Bal Tiga merupakan produk rokok paling laris dengan jaringan pemasaran yang luas. Pada dekade pertama berdirinya pabrik ini produksi rokoknya baru 1 juta batang perhari, tetapi pada periode berikutnya produksi meningkat menjadi 6 juta batang perhari dengan jumlah 8.000 pekerja. ${ }^{57}$ Seorang menantunya yang bernama M. Karmain yang semula bertugas sebagai Verkoper penjualan di Semarang dijadikan General Manager untuk membantu mengelola pabrik tersebut.

Satu tingkat di bawah Nitisemito ada pabrik milik H.M. Muslich dengan merek Tebu dan Cengkih dengan pekerja lebih dari 4.000 orang. Pada dekade pertama pabrik tersebut dapat memproduksi rokok kretek 2 juta batang perharinya, hingga tahun 1935-1939 perusahaan tersebut mampu memproduksi rokok lebih dari 2 juta batang perharinya. 58 Promosi yang dilakukan dalam memasarkan produk rokok kreteknya juga tidak jauh dari cara yang dilakukan oleh Nitisemito yang pada saat itu menjadi pionir strategi pemasaran modern yang banyak diikuti.

Hubungan sosial dalam bentuk mitra usaha sudah terjalin baik dengan pedagang di kota lain, sehingga memudahkan dalam memasarkan rokok

${ }^{56}$ Hanusz, Kretek the Culture, hlm. 43. Lihat juga Arsip mengani M. Nitisemito disarikan dari Der Kretek Koning M. Nitisemito.

${ }^{57}$ Margana, Kretek Indonesia, hlm. 61.

58Salam, Kudus, hlm. 33-34. 
kretek. Nitisemito dan H.M. Muslich awalnya menawarkan rokok kretek dari mulut ke mulut dengan memanfaatkan jalur distribusi perdagangan kain yang sudah terjalin. Mereka memanfaatkan teman dan sahabat untuk menawarkan produk rokok kretek kepada masyarakat luas. Pengalaman ditambah dengan jaringan yang luas mempermudah pemasaran rokok kretek pada jalur perdagangan di Indonesia.

Konsep tindakan ekonomi bisa dilihat dari transaksi yang dilakukan pedagang santri dalam mencari daerah pemasaran baru rokok kretek yang tidak akan lepas dari sebuah interaksi sosial. Terlebih tindakan ekonomi yang dijalankan selalu bersinergi dengan tindakan sosial. Jalinan kemitraan yang dilakukan Nitisemito dan H.M. Muslich mempunyai tujuan untuk mendapatkan imbalan keuntungan secara ekonomi. Selain itu mereka juga mendapatkan keuntungan sosial dengan semakin eratnya hubungan sosial yang terjalin untuk melanggengkan kemitraan bisnis.

Namun tidak hanya itu, konsolidasi sosial-ekonomi juga terjalin antara Nitisemito dan H.M Muslich dengan ikatan hubungan perbesanan di antara keduanya. Anak laki-laki Nitisemito yang bernama Soemadji Nitisemito menikah dengan anak perempuan H.M. Muslich yang bernama Siti Chasinah Muslich. ${ }^{59}$ Hubungan kekeluargaan yang terjadi antara kedua padagang besar itu secara tidak langsung tentu mempunyai motif ekonomi yang kuat. Supaya jaringan ekonomi diantara dua pabrik kretek besar ini semakin solid untuk menguasai pasar. Dalam perjalanannya banyak pedagang santri yang mengadakan hubungan pernikahan diantara anak-anaknya untuk membangun konsolidasi ekonomi yang kuat.

Kegiatan ekonomi yang dilakukan pedagang-pedagang santri ini pasti ditentukan oleh kegiatan produksi, seperti elemen lahan, tenaga kerja, dan modal. Namun kegiatan produksi, distribusi, dan konsumsi sebagai aktivitas ekonomi pada kenyataannya tidak dapat dipisahkan dari kehidupan sosial. ${ }^{60}$ Semua kegiatan tersebut mengandalkan interaksi sosial antara individu satu dengan individu lain dan individu dengan kelompok dalam lingkungan sosial industri. Terjalinnya hubungan sosio-ekonomi yang baik tanpa adanya kesenjangan diantara kedua kepentingan, menjadikan perjalanan ekonomi akan berlangsung harmonis.

\section{PENUTUP}

Berdasarkan data-data yang didapatkan dalam penelitian, dapat diambil beberapa kesimpulan sebagai berikut. 1) Latar sosio-ekonomi yang terjadi di Kudus sepanjang tahun 1912-1918 menjadi acuan pedagang santri untuk meraih kemajuan ekonomi. Kedatangan orang-orang Cina sebagai orang asing membawa ketidakseimbangan dalam tatanan kehidupan sosial-ekonomi di masyarakat Kudus. Persaingan ekonomi yang diperkuat oleh dorongan agama

\footnotetext{
${ }^{59}$ Nitisemito, Raja, hlm. 97.

60Pheni Chalid, Sosiologi Ekonomi (Banten: Universitas Terbuka, cetakan ketiga April
} 2012), hlm. 5 . 
menjadikan rasa kebencian pedagang santri dan masyarakat Muslim Kudus semakin memuncak. Konflik pada Oktober 1918 menentukan suatu variabel yang menunjukkan tingkat intensitas kekerasan dalam interaksi sosial di masyarakat Kudus. 2) Pedagang santri mulai mampu menancapkan kaki menguasai ekonomi di Kudus pasca kerusuhan. Nitisemito dan H.M. Muslich mampu membangun kemajuan pabriknya dengan tekun dan sabar. Mereka mampu membuat sistem produksi secara efisien. Keuletan, kreatifitas, ketekunan, dan ketakwaan yang membuat pedagang santri tetap bertahan di tengah pergolakan politik dan sosio-ekonomi yang sangat dinamis pada masa kolonial Belanda. 3) Pedagang santri mampu melakukan berbagai tindakan ekonomi rasional sebagai pertimbangan untuk meningkatkan dan memajukan pabriknya. Pedagang-pedagang santri ini juga selalu mengusahakan sistem pemasaran modern. Mereka juga menjalin jaringan hubungan kemitraan secara kekeluargaan dan memperkuat hubungan relasi ekonomi maupun sosial yang berdasar kepercayaan antara sesama pedagang.

\section{REFERENSI}

\section{Buku}

Bertrand, Jacques. Nasionalisme dan Konflik Etnis di Indonesia. Yogyakarta: Ombak, 2012.

Budiman, Amien dan Onghokham. Kretek, Lintas Sejarah dan Artinya Bagi Pembangunan Bangsa dan Negara. Kudus: PT. Djarum, 1987.

Castles, Lance. Tingkah Laku Agama, Politik, dan Ekonomi di Jawa: Industri Rokok Kudus. Jakarta: Sinar Harapan, 1982.

Chalid, Pheni. Sosiologi Ekonomi. Banten: Universitas Terbuka, cetakan ketiga April 2012.

Geertz, Clifford. Agama Jawa; Abangan, Santri, Priyayi dalam Kebudayaan Jawa Terj. Aswab Mahasin dan Bur Rausanto. Jakarta: Komunitas Bambu, 2013.

Damsar, Pengantar Sosiologi Ekonomi. Jakarta: Kencana Prenada Media Group, Cetakan Kedua, 2011.

DM, Abhisam, Ary, Hasriadi, dan Harian, Miranda. Membunuh Indonesia Konspirasi Global Penghancur Kretek. Jakarta: Penerbit Kata-kata, cetakan kedua, Maret 2012.

Habib, Achmad. Konflik Antaretnik di Pedesaan Pasang Surut Hubungan Cina-Jawa. Yogyakarta: LKIS, 2004.

Hanusz, Mark. Kretek the Culture and Heritage of Indonesia's Clove Cigarettes. Jakarta: Equinox Publishing, 2003.

Harahap, Parada. Indonesia Sekarang. Jakarta: Bulan Bintang, 1952. 
Jalil, Abdul. Spiritual Enterpreneurship (Studi Transformasi Spiritualitas Pengusaha Kudus). Disertasi Program Pascasarjana Institusi Agama Islam Negeri Sunan Ampel, Surabaya. Yogyakarta: LKIS, 2013.

Kartodirjo, Sartono. Pendekatan Ilmu Sosial dalam Metodologi Sejarah (Yogyakarta: Ombak, 2014.

Margana, Sri. Kretek Indonesia dari Nasionalisme Hingga Warisan Budaya. Yogyakarta: Jurusan Sejarah Fakultas Ilmu Budaya Universitas Gajah Mada dan PUSKINDO, 2014.

Masyhuri. Bakar Pecinan. Jakarta: Pensil-324, 2006.

Nitisemito, Alex S.. Raja Kretek Nitisemito. Kudus: t.p, 1980.

Poloma, Margaret M.. Sosiologi Kontemporer. Depok: PT Rajagrafindo Persada, cetakan 9, Januari 2013.

Salam, Solichin. Kudus dan Sejarah Rokok Kretek. Kudus: PPRK, 1983.

Tan Boen Kim. Peroesoehan di Koedoes. Batavia: Drukkerij Goan Hong, 1920.

\section{Arsip}

Arsip keluarga Nitisemito yang disarikan dari buku Der Kretek Koning $M$. Nitisemito. Penulis dapatkan dari Badan Arsip dan Perpustakaan Provinsi Jawa Tengah pada 2 Maret 2016.

Arsip foto kelompok sandiwara keliling dari pabrik Bal Tiga Nitisemito. Sumber dari Badan Arsip dan Perpustakaan Pemerintah Provinsi Jawa Tengah.

Bijlagen Van Het Verslag Der Handelingen Van De Tweede Kamer Der Staten Generaal 1919-1920.

\section{Jurnal}

N, Said, "Gusjigang dan Kesinambungan Budaya Sunan Kudus (Relevansinya Bagi Pendidikan Islam Berbasis Local Genius)". Jurnal Penelitian Islam Empirik, Vol 6, Nomor 2, Juli-Desember (2013).

\section{Internet}

Albar, Muhammad Wasith. "Sejarah Perkembangan Pengusaha Pribumi dan Non-Pribumi Industri Kretek di Kudus 1908-1975” dalam ICSSIS, 2011. 